\title{
The 'Ties that Bind Us’: The Hidden Knots of Gay Marriage
}

\author{
Bronwyn Winter, University of Sydney
}

\begin{abstract}
Conservatives believe in the ties that bind us; that society is stronger when we make vows to each other and support each other. So I don't support gay marriage despite being a Conservative. I support gay marriage because I'm a Conservative. (David Cameron, Prime Minister of the United Kingdom, Keynote Speech at Conservative Party National Conference, Manchester, 5 October 2011).
\end{abstract}

Gay marriage has become a major transnational gay rights issue. It is considered a key marker of equal citizenship between gay and straight individuals: a step forward in the normalisation and thus de-stigmatisation of homosexuality. As Lisa Duggan has put it, 'marriage equality has become the singularly representative issue for the mainstream LGBT rights movement, often standing in for all the political aspirations of queer people’ (Duggan 2011: 1). The proposition that legalisation of gay marriage represents progress is assumed to be self-evident. Scholarship over the last two decades, however (such as Polikoff 1993; Duggan 2003; Ahmed 2006; Puar 2006; Browne 2011; Halberstam 2012), has challenged that assumption, and Puar in particular has noted that this 'progress' is concurrent with other forms of exclusion. In this article I will further explore these challenges in considering how states have used gay marriage to enhance their social-justice credentials and popularity while leaving other social justice issues, including some gay rights issues, unaddressed. I argue that gay marriage is a convenient liberal smokescreen that, in reassuring progressive elites (straight and gay), deflects the

PORTAL Journal of Multidisciplinary International Studies, vol. 11, no. 1, January 2014.

Stigma and Exclusion in Cross-Cultural Contexts Special Issue, guest edited by Annie Pohlman, Sol Rojas-Lizana and Maryam Jamarani.

ISSN: 1449-2490; http://epress.lib.uts.edu.au/ojs/index.php/portal

PORTAL is published under the auspices of UTSePress, Sydney, Australia. 
focus from neoliberal, so-called security and other discriminatory measures taken by states that are far more worrying for homosexuals (and indeed, many others) in the longer term. Further, I will examine the force of the religious right's opposition to gay marriage, which is unsurprising yet often startling in its vehemence. The force of this opposition, however, simultaneously reinforces the progressive credentials of governments adopting gay marriage and makes it difficult for anyone else who wishes to be considered progressive to maintain a critique of the 'marriage equality' agenda. As Michael Warner put it as early as 1999, in relation to the debate in the USA, 'there is something unfashionable, and perhaps untimely, about any questioning of gay marriage as a goal in politics ... At this point the only people arguing against gay marriage, it seems, are those homophobic dinosaurs' (Warner 1999: 120).

My main interest here is not with the individual motivations of lesbians and gay men who wish to marry nor even with the egalitarian rationale of the pro-gay-marriage social movement—although I will comment on the latter. It is the harnessing of the marriage rights agenda by states that is my concern. I will also move away from the copiously explored site of the USA to look at three other case study sites: Argentina, France and Australia. Argentina is one of six countries outside Europe to recognise same-sex marriage at the time of this writing. The others are: Canada (2005); South Africa (2006); Brazil, Uruguay and New Zealand (2013). France is the second most recent of ten European countries to legalise same-sex marriage (May 2013, a few days after Brazil), the most recent being the United Kingdom (July 2013). Other European bills are, at the time of this writing, under discussion in parliament in Andorra, Finland, Germany (where the September, 2013 re-election of Angela Merkel is nonetheless likely to delay legalisation), Ireland and Luxembourg. Outside Europe, Nepal and Taiwan are considering legislation.

As for Australia, it was among the first countries in the world to formally recognise same-sex relationships for immigration purposes (since 1982, with successive changes in legislation since that time). Although the current 'interdependency' framework for gay immigration purposes is distinct from that for married or de facto heterosexual couples, it does signal both a popular and institutional recognition of gay couple relationships. Notwithstanding current Federal opposition to gay marriage, opinion polls cited by Australian Marriage Equality indicate that 75 percent of Australians consider it 
only a matter of time before same sex marriage is legalised (AME website), no doubt all the more because some Australian states already recognise civil partnerships in one form or another.

These three countries are chosen, first, because they are culturally and geographically quite distinct yet present significant similarities as concerns their political, socioeconomic and legislative structures. They are all liberal capitalist democracies with a white and Western or Western-focused ruling class. They all have or are developing some sort of human rights framework within national or supranational legislation or statutory bodies: the European Union (EU) Convention on Human Rights, 1950; the Union of South American Nations (UNASUR) commitment to the formation of a human rights body, 2013; and the Australian Human Rights Commission (AHRC), set up in 1986. Second, gay marriage legislation is either quite recent or still under discussion (2010 in Argentina, 2013 in France and not yet legalised in Australia). Third, opposition to gay marriage in all three countries has been ferocious. While the Catholic church has been one of the main players in this opposition in all three cases, and while the basic argument among the opposition has been a defence of the heterosexual-based family unit, the types of alliances formed and the discursive construction of the opposition has presented national specificities. Fourth, in all cases, advocacy of gay marriage, by gay rights movements and the political class alike, has tapped into a globalised LGBT rights discourse, mobilising the rhetoric of equality, inclusiveness and human rights.

To date, the English-language scholarly literature has overwhelmingly focused on the USA, sometimes in a 'post-9/11' frame, with some examination as well of Australia and EU countries. There is little scholarly literature as yet on gay marriage debates in Argentina and France, in either English, Spanish or French, but a great deal of discussion in online media of various sorts. Most of the existing critiques revolve around some version of the ideas of 'homonormativity' (Duggan 2003), that is, assimilation of the 'right' homosexuals into a heterosexist societal structure, with concurrent exclusion of less assimilable sexual Others, and 'homonationalism' (Puar 2006), the harnessing of a 'gay rights' agenda to Western nationalist and imperialist ends (see also Polikoff 1993). 
Before discussing my three country case studies in more detail, I will briefly, for the purpose of contextualisation, situate gay marriage campaigns within the context of a global LGBT rights agenda, and canvass some of the existing critiques of these campaigns. The focus of this discussion is less on the national and transnational social movements themselves than on the gradual institutionalisation of LGBT rights discourse within the UN, as it is this UN-isation of LGBT rights that has provided the political and discursive framework within which national governments have placed their 'LGBT equality' agendas. It is well beyond my brief here to retrace the entire history of the global LGBT rights agenda (or indeed, of the shifts in nomenclature from 'gay,' to 'gay and lesbian,' to 'lesbian and gay,' to the inclusion of 'bisexual,' 'transgender' and occasionally 'intersex' and even 'queer'). Its beginnings can, however, roughly be traced to the late 1970s, with the formation in 1978 of the International Gay Association (which subsequently became the International Lesbian and Gay Association, and then, following the ‘alphabet soup’ imperative of including all sexual orientations and identities apart from heterosexual: the International Lesbian, Gay, bisexual, trans and intersex Association). Among other things, ILGA was the first lesbian and gay NGO to obtain special consultative status with the UN Economic and Social Council (ECOSOC), in 1993. Subsequent initiatives were the founding in 1990 in the USA of the International Lesbian and Gay Human Rights Commission and the IDAHO initiative: International Day Against Homophobia, initiated in Québec as a national event in 2003, and officially launched as IDAHO at the 2006 World Conference on LGBT Human Rights, also in Montreal, organised in July to precede the Outgames.

The 2006 Montreal conference could be considered a culmination point in the global mainstreaming of the global LGBT rights agenda that had been building over the previous decade and, in particular as concerns us here, of the global gay marriage campaign. At the time of the conference, gay marriage was already legal in four countries, three of them in the EU: the Netherlands (2001), Belgium (2003), Spain (2005) and Canada (2005). The so-called Montreal Declaration on LGBT human rights, which had been written by the international organising group well prior to the conference, was presented at the final plenary of the conference. It was also read by Martina Navratilova and Mark Tewsbury at the ensuing opening ceremony of the Montreal Outgames. The Declaration clearly articulated the gay marriage demand: 
LGBT people are not isolated individuals. We fall in love, and establish relationships and families-however configured. For many of us, these relationships and families are the most important parts of our lives. Unless they are legally recognized, our rights to equality and dignity cannot be fully secured ...

We therefore demand that all governments that have not yet done so reform family law in order to reflect the growing diversity of family life,

- by opening-up legal marriage to same-sex couples,

- introducing similar partnership rights for all unmarried couples, and

- $\quad$ ensuring equal access for all to every option for parenthood. (Montreal Declaration 2006).

The Montreal Declaration informed the Yogyakarta Principles adopted that November in Yogyakarta, Indonesia by a committee of human rights experts, chaired by the then UN Human Rights Commissioner and keynote speaker at the Montreal conference, Montreal native Louise Arbour. Principle 24 concerns 'The Right to Found a Family’: 'Everyone has the right to found a family, regardless of sexual orientation or gender identity. Families exist in diverse forms. No family may be subjected to discrimination on the basis of the sexual orientation or gender identity of any of its members' (Yogyakarta Principles 2006). This sentence is followed by a number of dot-points that articulate parenting and couple rights.

The Montreal Declaration and the Yogyakarta Principles remain firmly within the framework of the family as codified within the 1948 Universal Declaration of Human Rights. Not only do human rights include the right to marry and found a family, but the UN Declaration also tells us that the family is 'the natural and fundamental group unit of society and is entitled to protection by society and the State' (Article 16, para. 3). The Yogyakarta Principles may include a nod to 'diverse forms' of family but the idea of family itself, aligned to the heteropatriarchal nuclear-family model of modern capitalist nation-states, is not at any time questioned.

The two documents were nonetheless considered a landmark in advancing the global LGBT rights agenda, an agenda about which the reformist-assimilationist bases, and the ‘alphabet-soup’ grouping of all ‘alternative’ sexual and gender identities, have not been seriously questioned either by the UN and other inter- or supra-national rights bodies, democratic nation-states or gay rights organisations. This 'homonormalisation' did not, however, prevent the Yogyakarta Principles from meeting with strong opposition from a number of UN members when they were presented at the UN Human Rights Council on 26 March 2007, with the support of 54 member states. On 18 December 2008, a 
Declaration on Sexual Orientation and Gender Identity (a French and Dutch initiative), and signed by 66 member states (including all EU countries), was presented by Argentina to the UN General Assembly. The Declaration reaffirmed the principles of the 1948 UN Declaration, including 'the principle of non-discrimination which requires that human rights apply equally to every human being regardless of sexual orientation or gender identity’ (UN General Assembly 2008, article 3). A counter-declaration at the initiative of the Organisation of the Islamic Conference, and read by Syria, was presented the following day. Most recently, the UN Human Rights Council passed its first resolution on 'Human rights, sexual orientation and gender identity' (Resolution L.9 Rev.1, 16 June 2011).

The persistent opposition by most (albeit not all) Muslim countries to decriminalisation of homosexuality has provided a new means for Western and pro-Western nations to distinguish themselves as progressive in relation to the essentialised Islamic (terrorist) other. In her analysis of 'homonationalism,' Jasbir Puar argues that in tying 'the recognition of homosexual subjects, both legally and representationally,' to nationalist and imperialist agendas, thus constructing a specific 'biopolitical' profile of the gay citizen, Western homonormativist assimilation helps to reinforce the Othering of those beings deemed unacceptable within these biopolitics (Puar 2006: 9 ff). The 'Muslim world' becomes once again essentialised as a-historic, brutal and the anathema of progress and modernity. Much as ‘women’s rights’ were used as a moral justification for the 'War on Terror' in 2001 to 2003 (Delphy 2002; Winter 2002a; Winter 2006; Eisenstein 2007), 'gay rights,' defined homonormatively, have become the new indicator of Western moral superiority. We have gay marriage, gay businesses, gay TV shows, while they have stonings, rapes and honour killings. For Puar, writing within a US post-9/11 context, 'they' is the Muslim other, although the Othering does not stop there.

Yet, the fact remains that the countries most fervently opposed to any sort of rights for gay people are those where religion-Islam but also Christianity — and state are the most heavily imbricated. Homosexuality is, for example, illegal in Christian-dominated Uganda and Cameroon as well as in many Caribbean and Pacific-Island states that are also Christian dominated. It remains illegal in 77 countries and is punishable by death in five of these as well as in Muslim-controlled regions of Nigeria. On a national level, in 
2013 Nigeria became one of a number of countries to regress on gay and lesbian rights, adopting on 30 May a law condemning any gay or lesbian couples who marry to fourteen years in prison, with a ten-year sentence for gay and lesbian couples who merely show affection in public. With this sort of brutal opposition, largely fuelled by religious lobbies, it is not difficult to understand why gay marriage has become an international cause célèbre and it becomes difficult to argue against it if one wishes to be considered progressive.

It is, however, arguable, even demonstrable, that notwithstanding the vicious opposition of governments such as that of Nigeria, marriage is not at the top of the agenda in countries where even to exist as gay or lesbian is punishable by death, prison, corporal punishment, fines and/or various other forms of legally sanctioned economic discrimination and social ostracism. Yet our understandings of human rights are heavily influenced by positivist thinking: according to such thinking, human rights are incrementally obtained in a linear pathway of progress that inevitably moves forward and upward. The legal recognition of gay marriage and family, as the Montreal Declaration argues, has come to be seen as an essential (final?) step in 'fully securing' gay and lesbian 'dignity and equality,' and thus a marker of the 'advanced' state of democracies. That gay marriage is not necessarily the most pressing matter in Uganda or Saudi Arabia does not, for its advocates, mean that it does not represent the finality of gay rights for citizens of those countries. According to such arguments, Uganda and Saudi Arabia have simply not 'advanced' that far yet.

To set up gay marriage as the pinnacle of recognition of gay 'dignity and equality,' as per Article 16 of the 1948 UN Declaration, is to frame 'LGBT rights' in a particular way. I am not here arguing for culturally-relativist definitions of human rights (such as the 1981 Islamic Declaration), as a counter to the presumed 'Western hegemony' of human rights philosophy. I do believe it is possible to identify a common humanity and fundamental needs of every human being, whatever particular approach one takes: human rights, human capabilities (Nussbaum 2000) or so on. I am, however, suggesting that what the authors of the 1948 Declaration decided were human rights is open to both interpretation and contestation, as feminists have argued for many decades in relation to the family, which is the primary site of the gendering of social relations. As such, it is also the basis for explicit or tacit ideological, legal and cultural codification not only of 
what women are and what women's place is in society, but also of the forms of punishment women are to receive if they transgress. That most violence against women happens within or in relation to a family context is noteworthy. I note in passing that gay marriage has not and will not resolve the issue of domestic violence, and am concerned at the naivety of the idea often advanced by gay marriage advocates that the latter will somehow in itself subvert or transform the institution of marriage. I have to date observed nothing and seen no research that bears out such an assumption.

These codes are so deeply ingrained in our cultures as to be considered natural (Winter 2002b). Gender, for example, is considered a 'normal' social division and basis for social organisation, and to be properly gendered one has to exhibit certain physical and psychological characteristics. The politics of transgender has largely been built on that premise: that gender is a normal part of social relations, and if one has the misfortune to be born into the 'wrong' gender, then this should be surgically changed. The idea that social relations might be much improved, and 'dignity and equality' more wholly realised, by doing away entirely with the concept of gender, has little currency in global LGBT rights conversations.

Indeed, it appears to be inconceivable, so overwhelming is the necessity to have a gender - on every identity document, every form one fills out, through every act of selfidentification —as is the necessity to be situated in relation to official coupledom. Citizenship is in fact not only sexual but also marital—as David Cameron, cited at the beginning of this article, clearly reminds us. To be married—for both heterosexuals and homosexuals - is to better conform to what it is to be fully human, as encoded in the 1948 Universal Declaration of Human Rights among other documents. Families are at the base of social fabric; they are protected by states through legislation and cultural norms. To be part of a family is to more fully exist. To be part of a legally recognised couple is to more fully exist. To procreate or to adopt children is to more fully exist. In doing so, one conserves 'the ties that bind us' as a nation, as David Cameron reminds us. The implicit flipside of this equation is that not to be married and procreate means that one less fully exists, is socially, culturally and emotionally deprived and indeed deficient. Will the unmarried and childless gay man or lesbian become the new pariah of a homonormalised nation? 
As pointed out by Puar and by others such as Alexandra Chasin (2000), who analyses the impact of capitalist consumerism on gay politics, the national 'us' is defined by elites and their social, financial and cultural capital. As a core demand of the global LGBT rights movement, gay marriage remains the province of liberal and largely secularised capitalist democracies. As a sign of gay normalcy, it is also, in this global neoliberal context, necessarily synonymous with cosmopolitanism. Assimilated gay culture is one of the attributes of prosperous global cities. It is a selling point of innercity tourist culture, flourishing in Oxford Street or the Inner West in Sydney, Barrio Norte or San Telmo in Buenos Aires or the Marais in Paris. It is noteworthy that in both Argentina and France, the national and international media focus following the passage of the gay marriage laws was on urban professional white men (for example: Pink News 2010; Le Monde 25 May 2013; Chrisafis 2013). To be gay and to be married is to have access both to full citizenship of one's country and to be an ambassador for that country, or at least its cosmopolitan urban centres, as a desirable place to travel, live and do business - and indeed, migrate. In immigration legislation in most countries, immigrants married to a national have easier access to visas and shorter waiting periods for work and residency permits than civil-union partners or those in non-formalised couple relationships.

Absent from this glowing scenario of the modern, egalitarian and cosmopolitan nation is the fact that marriage operates to reinforce already-existing differentiation between classes of immigrants. While gay marriage legislation and the improved immigration opportunities it opens up are certainly not colour-coded in the letter of the law, screening processes are nonetheless usually different depending on the country of origin of the spouse. For example, those coming from the less wealthy countries of the socalled Global South come under greater suspicion of having entered into marriages of convenience. Also, in some cases, as has been noted in relation to France's new law, existing bilateral agreements concerning which country's law is to be observed concerning recognition of marriage can work against transnational couples (Trouillard 2013). Moreover, gay marriage does nothing to address the ongoing issue of asylum for lesbians and gay men for whom liberal democracies are more often than not closely guarded fortresses (Jansen \& Spijkerboer 2011; Winter 2012). Even as these democracies open their doors (just a crack) to gay asylum seekers, they reinforce both the reification of the cultures and countries of origin as a-historic and backward, and the 
construction of a performative 'gay' identity aligned to a Western stereotypical model (Luibhéid 2008; Millbank 2009). In fact, argues Sandip Roy, 'legalizing same-sex marriage may be less about gay rights and more about codifying an ideal of European values - another brick in the wall of Fortress Europe before it’s too late' (Roy 2005). How, asks Ilgin Yorukoglu, writing about Turkish gay minorities in Germany, 'do we explain this double standard, one that encourages tolerance and invites gay tourists and the "creative class" to the table on the one hand, while calling for stricter border controls to curb immigration on the other?' (Yorukoglu 2010: 435).

More broadly, as I suggested at the beginning of this article, actions by governments in favour of gay marriage cost nothing; this is particularly the case for left-leaning governments for which the religious right is not usually a key constituency. On the contrary, in fact, support for gay marriage improves governments’ popularity among a significant electoral demographic, and even right-wing governments who may be assumed to be more attentive to religious hardliners have learned to play to popular opinion, as we will see presently in the case of the new Abbott government in Australia. Support for liberal-democratic social justice issues like gay marriage is also useful in deflecting attention from other measures that are far less likely to advance gay, or anyone’s, human rights, as we will see in looking at all three case studies.

\section{Argentina}

In 2010, Argentina became the first country in Latin America, and the tenth in the world, to legalise same-sex marriage. This move has resulted in the qualification of Argentina, on numerous online media and encyclopedia sites, as the most 'advanced' Latin American country as concerns gay rights. The Senate approved the law on 14 July, by 33 votes to 27, with three abstentions, after a fourteen-hour debate. The vote was televised live and Peronist president Cristina Kirchner also signed off on the law on national television on 22 July. According to an article in the British press, five hundred marriages were celebrated between that date and 25 December (that number increased to 6,000 by June 2012), and some three hundred suppliers were explicitly targeting the gay marriage market. Gay (male?) spouses-to-be were reported to be much bigger spenders than their heterosexual counterparts, by some 30 percent (Kelly 2012). A 'gay marriage’ tourism industry has even developed, oriented primarily around Buenos Aires, 
the 'gay capital' of South America, although some tourism websites also provide advice on regional Argentinian destinations such as Rosario, Mendoza, Bariloche and Ushuaia.

Yet some commentators have noted that gay marriage, often framed, as I have suggested above, as the culmination of progress on gay rights, has in Argentina lain more at the beginning than at the end of the road. Discrimination and violence against gay men and lesbians in regional Argentina-anywhere, in fact, outside the cosmopolitan porteño culture of central Buenos Aires-continues virtually unimpeded, and gay marriage has done little if anything to alter this. The extent of the problem was brought home some months prior to the passage of the gay marriage law by a murder case that has become a cause célèbre among LGBT rights activists in Argentina (Dillon 2011; Greenfield 2011). On 7 March 2010, 27-year old Natalia 'Pepa’ Gaitán, a highly visible and butch-looking lesbian living in the city of Córdoba, was murdered by her girlfriend's stepfather, Daniel Toledo, who objected to his stepdaughter leaving home to leave with Gaitán (Greenfield 2011). A wave of local protest ensued, with graffiti and posters denouncing this murder as a hate crime. As lawyer Natalia Milisenda put it: 'this is a case of gender violence, which is not recognised in public policies, but which victimises many lesbian women, simply for the fact that they are women and that they are freely exercising their sexuality' (cited in Vinter 2010). Yet the court refused to acknowledge that Gaitán was targeted as a lesbian and as a woman refusing to conform to feminine stereotypes, and Toledo was sentenced to fourteen years imprisonment for ‘domestic violence’ (Greenfield 2011). The following year, the 8 March international women’s day protest in Córdoba commemorated Gaitán’s murder, focusing on femicide and other forms of violence against women including lesbians (Qualiafolk 2011).

Other forms of violence against women continue to be a grave problem in Argentina. A few days after the gay marriage law was signed, there was a large demonstration in Buenos Aires in favour of fully legalising abortion, which is subject to strict restrictions under the 1921 Penal Code, still in force. The Code qualifies abortion as a 'crime against life,' and allows it in only two exceptional cases: where there is immediate risk to the mother's life and in the case of rape of a mentally incompetent woman (that is, developmentally disabled or mentally ill). In practice, however, even in these cases some doctors will raise conscientious objections and refuse to perform the abortions. One is led to ask why, in these two areas that are both related to the idea of sexual 
citizenship and sexual rights, and that have historically met with resistance for the same reasons: 'nature, morals and “common good”' (Rawson 2012: 177, my translation), there have been such diametrically opposing political outcomes. The outcomes are all the more surprising because in other countries, the recognition of women's sexual and reproductive rights has preceded the recognition of gay relationships by many decades. Milagros Belgrano Rawson suggests that this apparently paradoxical difference in outcome is related to the ongoing refusal by the state to consider women as full sexual citizens (Rawson 2012: $177 \mathrm{ff}$ ). Rawson also suggests that the greatest impact of illegal abortion is on poor women, as richer women have access to safe but costly abortions in Argentina (illegal) or overseas (legal).

While it would be counterproductive and indeed absurd to consider the continuing struggle of Argentinian women for freedom from violence and for full reproductive and sexual rights as somehow in 'competition' with gay rights, it is nonetheless telling that a relatively cosmetic issue, that of gay marriage, has been addressed while more substantive and even legally-supported discriminations and violence against gay men and all women, straight or lesbian, persist. Rawson has offered a second reason for this 'rights' discrepancy: a certain political opportunism by president Kirchner and her party (Rawson 2012: 177 ff). Kirchner, like her late husband and former president Nestor, was elected on, among other things, a human rights platform.

Moreover, in the wake of the Global Financial Crisis Argentina's inflation was running at some 25 percent in 2010, its highest level since the devaluation of the peso in 2002, and the government and president, in the lead up to elections the following year, were dogged by allegations of corruption and defections from the right wing of their Peronist ranks. Kirchner badly needed to score some political points and show the world that Argentina could hold its own among richer, more 'advanced' democracies of the West. Argentina’s Western aspirations are not only political and economic, they are also cultural, with strong affinities with Europe (particularly France and Italy, perhaps more so than Spain in some respects). Indeed, Argentina is often considered the 'whitest' country in Latin America, both statistically (an estimated 97 percent of the population is of European origin: CIA statistics), and because of the (need to reaffirm) identity, image and aspirations of middle-class porteños (inhabitants of Buenos Aires) (Joseph 2012). 
Argentina nonetheless remains a strongly Catholic country, even if many Argentinian Catholics, like French Catholics, are more lapsed than practising. If Kirchner stopped short of opposing the Church on abortion —on the contrary, she herself has clearly declared on more than one occasion that she is against abortion — she did find herself at loggerheads with the then Cardinal Jorge Bergoglio, now Pope Francis, over gay marriage. The relationship between Bergoglio and Kirchner had been tense for some time, with Bergoglio going so far as to accuse Kirchner of 'persecuting' Argentinian Catholics. The tension reached a peak at the time of legalisation of gay marriage, with Bergoglio prominently at the head of demonstrations against the law, claiming gay marriage was the work of the Devil.

Apart from gay marriage (and abortion) Bergoglio also took the Argentine government to task over the issue of poverty in Argentina. (Such a stance is reminiscent of that taken by George Pell in Sydney. Pell has always been a staunch defender of Australia's poor, but an equally staunch opponent of gay rights, so much so that he inspired the mocking lead float in Sydney’s popular Gay and Lesbian Mardi Gras Parade in 2004, 'St Fairy's,' a parody on St Mary's, Sydney’s Catholic cathedral.) The issue of poverty in Argentina is all the more vexed because the methodology and measures used by the official government statistics office, Indec, are wildly at variance with those used in a parallel study by the Argentine Catholic University’s Observatory for Social Debt (ODSA). Indec puts the 2012 poverty rate at some 6 percent of Argentina's population of 40 million, while ODSA puts it at around 26 percent (ODSA 2013, Mercopress 2013). The poverty rate in Argentina can also be linked to race and origin: regional migration (that is, from other South American countries) is the main source of Argentina's lowand unskilled labour force (often undocumented) and accounts for roughly three quarters of all immigration.

The legalisation of gay marriage in Argentina is thus, notwithstanding the global context, very much a local story. Its passage with much fanfare at a time when Argentina was facing multiple political and economic difficulties, enabled the Argentine state simultaneously to position itself as the vanguard of modernity, human rights and 'sexual citizenship' in Latin America and to gloss over some other, deeper problems, such as the refusal of complete sexual citizenship to women more generally, alleged 
political corruption and ongoing poverty, in a country where some 40 percent of the population is under 25 .

\section{France}

If in Argentina the legalisation of gay marriage appears to be a form of opportunistic grandstanding by a centre-left regime confronted with political and economic woes in other areas, the politically and sometimes physically violent French gay marriage debate has emerged, as French political debates often do, as a battle for the meaning of the Republic and the prerogative to define it.

The 'against' campaign has been particularly strong, its main organisers being a coalition called La Manif pour tous (Demonstration for all), so named as a counterslogan to the Mariage pour tous (Marriage for all) slogan of the pro-gay marriage campaign, which was also the name commonly given to the bill to open marriage to same-sex couples, that became law on 17 May 2013. The Manif pour tous, a coalition of a number of organisations, although many of them exist in name only, claimed its 13 January 2013 demonstration against gay marriage to be the most significant mobilisation of the right since 1984. In that year, parents, teachers and priests mobilised against a proposal to increase government control of (mostly Catholic) private schools, bringing about the downfall of the Mauroy government, the most progressive of the Mitterrand years.

Although less than half the size of the 24 June 1984 demonstration, the 13 January one was certainly large, with 800,000 or 340,000 participants (depending on whether one believes the organisers' figures or those of the police) (Hopquin \& Laurent 2013). It was certainly much larger than either the 16 December 2012 or 27 January 2013 demonstrations in favour of gay marriage, which indicates that the use of numbers of people demonstrating as the primary measure of the success of a political movement is ill-advised, given that Manif pour tous failed where Mariage pour tous succeeded.

The size of the Manif pour tous mobilisation is nonetheless indicative of the deep-seated Catholic-based conservatism that continues to exert influence in France, which is simultaneously the pioneer of Republican secularism and the 'eldest daughter of the Catholic Church' (because of the 496 conversion of Clovis, King of the Franks and of Gaul, who consequently became the Church's first son). In keeping with these co- 
existing and sometimes warring, sometimes cooperating values, the imagery and rhetoric used by the Manif pour tous, like those used by the French extreme right party The National Front, combined these ‘two Frances' into a message aimed at claiming the moral high ground in the latest battle for the Republic.

The Manif pour tous expresses its opposition to gay marriage as follows:

The 'Marriage for all' bill radically overhauls the Civil code by systematically removing the words 'husband,' 'wife,' 'father' and 'mother' in favour of asexual and undifferentiated terms (notably 'parents'). This bill thus intends to legally remove sexual difference and calls into question the foundation of human identity: sexual difference and the filiation that results from it. (Manif pour tous website 2013, my translation).

One of the most powerful tactics used by the Manif pour tous has been the Mariannes pour tous. Marianne is the feminised symbol of the Republic, emerging from popular culture among the French revolutionaries to become celebrated in statues, busts, coins and stamps, and used discursively in a range of political debates (Winter 2009). She has even become part of the official logo of the Republic (since 1999): her profile is featured in reverse silhouette as the white stripe of the French blue-white-red flag. Marianne’s metonymical force is difficult to underestimate. Today, (s)he who says 'Marianne’ says 'the Republic': its values, its institutions, its political culture.

In the various demonstrations of the Manif pour tous, groups of Mariannes pour tous have featured prominently. All young and long-haired, and mostly albeit not all white, the Mariannes pour tous appear clothed in flowing white dresses with the red Phrygian bonnets (that came to symbolise liberty at the time of the Revolution) decorated with tricolour rosettes. They typically wear sashes reminiscent of beauty contests showing the region they come from (Limousin, Brittany and so on), and hold aloft copies of the French Civil Code, which the May 17 law amended. Following the adoption of the law, they have demonstrated wearing gags to symbolise the 'silencing of democracy.' The Mariannes pour tous also have a Facebook page.

In sporting the regalia of the Republic and carrying one of its key political and legal symbols, the Civil code (dating from the Napoleonic era of codification of French law), the Mariannes pour tous embody the Republic: both the importance of the centralised state and the equally important rights and duties of citizens. Through their youthful (reproduction-ready) femininity, wearing sashes that denote not Republican departments 
but pre-Republican regions, the Mariannes pour tous recall not the revolution but the counterrevolution, the France profonde of local cultures and their identification with the land and the Church, that stands in opposition to hegemonic Paris. Embodying this mixed imagery, and standing behind, under or alongside the Manif pour tous banners and placards showing an image of a father, a mother, a son and a daughter, the Mariannes pour tous reinforce the idea that the Republic is synonymous with the heterosexual nuclear family, anchored in the deep traditions of French culture.

The opposition to gay marriage in France has also involved some violent incidents, the most extreme of which being the 21 May 2013 suicide of extreme-right historian and essayist Dominique Venner, who shot himself in front of the altar of the Notre Dame Cathedral in Paris, an act witnessed by some 1,500 people. A few hours previously, he had published a text on his blog calling on the Manif pour tous not to stop opposing gay marriage but to extend their campaign to opposing an Islamic takeover of France through immigration. To make this opposition count, wrote Venner, 'new, spectacular and symbolic gestures' would be needed to 'rock people out of their drowsiness, shake up anesthetised consciences and awaken the memory of our origins' (Venner 2013). Venner's action was certainly spectacular, and as Greens Deputy Noël Mamère put it in his own blog a few days later, it 'adds to the rising power of a grassroots fascism that is corrupting much of the French right' (Mamère 2013).

The force of the opposition to gay marriage in France, and the sort of symbolism and rhetoric it has deployed, makes it very difficult to take a critical attitude towards the French gay marriage campaign. Like other polarising debates such as that over the Islamic headscarf since 1989, or the 2009 'national identity' debate initiated by then president Nicolas Sarkozy, the gay marriage debate has become imbricated with a broader ideological battle for the Republic.

Yet, in looking at the carefully orchestrated 29 May broadcast of France's first gay marriage, it becomes clear whose Republic has won for the moment. The marriage, between two youngish to middle aged white professional men (one a 40-year-old business owner, one a 30-year-old public servant), took place in Montpellier, dubbed France's most gay-friendly city by gay e-zine Têtu, and was celebrated as are all marriages in France, in the city hall. According to gay rights campaigners this marriage had been in preparation for many months before the passage of the law, with both 
socialist party mayor of Montpellier, Hélène Mandroux, and the couple in question, lobbying to have the first official marriage celebrated there (Thomas Fouquet-Lapar, personal communication, 4 October 2013). The ceremony had easy-listening marriage music to accompany it, being preceded by 'L.O.V.E.,' sung by Nat King Cole, and followed by Frank Sinatra singing 'Love and marriage go together like a horse and carriage.' Before marrying the couple, Mayor Mandroux, standing between a portrait of president François Hollande and a bust of Marianne, gave a speech in which the government's version of the link between marriage and the republic was made clear. In advocating respect for others and respect for differences, Mandroux reminded her large audience that this respect is core to French values. By adopting the 'marriage for all' law, said Mandroux, France, the 'country of human rights,' advanced in its modernisation, moving ever closer to the values of liberty, equality and fraternity that are the 'fundamental values' of the Republic. 'It is through these values that guide us, inspire us and that are beyond us, that we honour the greatness of politics and the legitimacy of the mandate that is given us' ('us' being the government) (Mandroux 2013, my translation). Mandroux added that in being able to 'live their love in the light of day' through the institution of marriage, gay men and lesbians had now 'gained access to the same rights and the same duties' as all other citizens (the idea of citizenship in France involving both in relatively equal measure). The message that Mandroux, perhaps unintentionally, conveyed in this last statement, is that access to full citizenship necessarily goes together with (access to) marital status. Whatever progressive aspirations Mandroux, Hollande, Christiane Taubira (Justice Minister and author of the law) and French gay rights movements may have, the rhetoric employed by Mandroux (as well as by Hollande, whom she cited) harnesses gay marriage to the service of the Republican nation as firmly as the love horse is harnessed to the marital carriage.

\section{Australia}

What, then, of Australia, which as noted above was a world leader in recognising samesex relationships for the purpose of migration, and yet is the only of the three case study countries in this article to resist recognition of gay marriage? In the first gay immigration test case in 1982, lawyer Betty Hounslow based her arguments on an interpretation of the ‘compassionate and humanitarian' provisions in the then immigration law. It was also around that test case that the Gay and Lesbian Immigration 
Task Force (GLITF) was founded in Sydney, and started both lobbying for changes in the law and providing legal advice and support for gay and lesbian binational couples. Notwithstanding the efforts of the GLITF and others to have laws introduced that reflected the reality and diversity of lesbian and gay couples, the procedures that the Australian state incrementally developed from that time (first special category 'interdependency’ visa 1991, equal status with de factos from 2009) were firmly aligned with 'organis[ing] sexuality around the heteronormative institutions of intimacy and the family' (Yue 2008: 239-40). The 'proof' of cohabitation and relationship authenticity that was demanded consisted essentially of financial and legal documentation: joint bank accounts, rent receipts and so on, so that gay couples were forced into a marital merging that they otherwise may not have wished. Moreover, successive iterations of the procedures have increasingly required justification of periods of cohabitation outside Australia before applying for migration of the non-Australian national.

These immigration provisions, along with the strong gay cosmopolitanism of Australia's major cities (the Sydney Gay and Lesbian Mardi Gras Festival being one of the country's major tourist income earners) nonetheless positioned Australia as one of the world's more gay-friendly countries. One might have expected, in a country where 'homonormativity’ seemed to be everywhere-in gay urban culture, businesses, in television shows and film, among prominent gay citizens such as Greens leader Bob Brown, High Court judge Michael Kirby, the reverend Dorothy McRae McMahon and a range of entertainers and writers, not to mention 'allies' such as politician Clover Moore (Mayor of Sydney at the time of this writing) — that gay marriage would naturally follow. Then along came John Howard.

The Howard government, in power in Australia for a little under twelve years between 1996 and 2007, is often viewed as the most right wing in Australia's history, although there is disagreement over whether Howard sat to the right of Liberal Party founder and Howard role model Robert Menzies, or simply followed in the latter’s footsteps, adapting his politics to a different era. Among the many acts for which the Howard government is remembered is then Attorney General Philip Ruddock’s Marriage Amendment Act (2004). That law amended the 1961 Marriage Act, which had not actually defined marriage, as follows: 
Marriage means the union of a man and a woman to the exclusion of all others, voluntarily entered into for life (Article 5 [1]).

Certain unions are not marriages. A union solemnised in a foreign country between: (a) a man and another man; or (b) a woman and another woman; must not be recognised as a marriage in

Australia (Article 88EA).

Gay marriage had not been the major issue for LGBT rights campaigns in Australia at that time, certainly not to the extent that it was in some other countries, but the Marriage Amendment Act, that clearly reinscribed sexual citizenship as heterosexual citizenship, was the proverbial red rag to a bull. It prompted the formation of Australian Marriage Equality (AME), founded the same year by activists from left wing political parties, the Gay and Lesbian Rights Lobby and other groups. AME launched a national campaign for gay marriage the following year and has not let up since. The campaign has been supported by the Greens, trade unions, and various other groups and individuals not previously known for their attachment to marriage. It seems in retrospect that the surest way to get Australian gay men and lesbians interested in gay marriage was to explicitly forbid it. The Australian gay and lesbian, or LGBT movement, now appears to be firmly part of the global gay marriage campaign, and those of us who, like Yue in relation to gay immigration, raise concerns about homonormativity, are relegated to the all-butsilent margins. Even staunch lesbian feminists who have previously been marriage resisters rather than marriage advocates have difficulty in appearing as killjoys if other lesbians demonstrably want to get married, as evidenced by many conversations I have had with activists over the years. As women, after all, we have too frequently come up against prohibitions to wish to impose them on others. Many Australian feminists thus, bizarrely, find themselves demonstrating for gay marriage — or have difficulty in maintaining their broader critique of marriage as it is perceived to be 'anti-' gay rights.

A second red rag was added by Julia Gillard, former Australian prime minister. One might have thought that Gillard, who comes from the Left faction of the Australian Labor Party (ALP) would have been fully in support of a measure deemed progressive in the logic of 'small-l' liberalism that informs our Western democracies. One might also have thought that the recent New Zealand legalisation, and the fact that Gillard's friend and one of her main political lieutenants, Finance Minister Penny Wong, is not only an out lesbian living in a couple but also has a child with her partner, would sway Gillard. Not so: Gillard resolutely continued to oppose gay marriage, and the position of an ALP conscience vote and a Liberal-National 'No' vote during her term ensured that 
gay marriage could not possibly become legal in Australia. A bill put by ALP backbencher Stephen Jones in September 2012 was crushingly defeated in the House of Representatives by 98 votes to 42 . Yet it may simply have been that Gillard, who lives, unmarried, with her partner Tim Mathieson, was not in favour of marriage tout court. Her position may thus be less conservative than may have been assumed.

Bizarrely, it is the new right-wing government in Australia that may end up showing itself more amenable to considering gay marriage. Prime Minister Tony Abbott, sensitive to opinion polls, has declared himself open to a conscience vote in his party to replace the former blanket opposition. Yet in December 2013, the Federal Government succeeded in its constitutional challenge to the Australian Capital Territory's gay marriage law, which was thus overturned by the High Court, returning hundreds of Canberran gay couples, who had married immediately the law was passed, to an unmarried state after only a few days of wedded bliss. At that time Abbott remained cagey on whether he would follow through on a national conscience vote (Murphy 2013), but has since turned his attention to matters more clearly in line with LiberalNational heartland values: the introduction of a new raft of 'security' legislation and negotiations with Cambodia, one of the world's most corrupt countries, on outsourcing detention of asylum seekers.

In Australia, then, perhaps more than elsewhere, the campaign for gay marriage largely took the form from the outset of 'how dare you say we can't,' perhaps rather more than 'we really, really want this in order to be considered full citizens.' Nonetheless, Australian Marriage Equality cites polls that place support for gay marriage in Australia at 64 percent, with the proportion rising to 81 percent among 18-24 year olds (AME website), and AME national convenor Rodney Croome anticipates mass gay marriage travel to neighbouring New Zealand (cited in Packham 2013). This will surely be as good for the New Zealand tourism industry as it has been for the porteño one in Argentina. AME also frames marriage equality as being 'about extending the privileges already enjoyed by the majority to an excluded minority' (AME website). Yet in Australia, getting married can lead to new forms of underprivilege, such as loss of financial autonomy, contrary to what is the case in France for example.

In 2008, the ALP government under the then Prime Minister Kevin Rudd brought in reforms to grant same sex couples de facto partner status. This measure, trumpeted as 
progressive, and despite some family-oriented benefits such as childcare rebates, in fact impacted negatively on many welfare entitlements such as pension payments and unemployment benefits, meaning that same-sex couples, who may have been living for years as legally and financially single, stood to lose out considerably under a new obligation to register their relationships with government welfare agency Centrelink. Under Australian law, their relationship status, including means-testing of partner income, impacts on their entitlement to welfare payments such as age pension and unemployment benefits in exactly the same way as marriage would. Older women, whose income over the course of their lifetime had typically been lower than that of men, were rendered particularly vulnerable. This measure also impacted culturally, as many older gay men and lesbians remained closeted and feared forced 'outing' by the new measures. In mid-2009, the Welfare Rights Centre, which has engaged in advocacy for affected populations, reported receiving roughly ten calls a day from gay men and lesbians, many of them older, concerned about the impact of these changes (Welfare Rights CEO Maree O’Halloran, cited in Peatling 2009).

Those callers have reason to be concerned, particularly if they are women. The 2012 Poverty in Australia report of the Australian Council of Social Service (ACOSS) shows that poverty in Australia, as defined under very austere OECD terms, has not gone down in the period from 2003 to 2010, but risen slightly, and that roughly 12 percent of Australians are living below the poverty line, with the proportion of women being higher at 13.5 percent. Those on unemployment benefits and age pensions are particularly vulnerable, as are those living in expensive cities such as Sydney (now rated the third most expensive in the world; it is also home to one fifth of Australia's population). 'Recognition' of same sex partnerships as outlined above can only exacerbate the problem for those populations. It is one of the more unusual circumstances in the global debate about gay marriage, in which 'homonormalisation' can in fact increase other forms of stigmatisation, not for others, but for the very same people. The saying 'Be careful what you wish for' comes to mind.

Recognition of gay marriage has also recently been put forward in Australia as important for attracting skilled migration (even though de facto couples are now recognised as discussed above). Brian Grieg, former Senator with the now defunct centrist party The Australian Democrats and West Australian convenor of Australian 
Marriage Equality, commented in May 2013 that there was a pressing need for skilled migrants, but that married gay professionals from Western countries (Grieg referred only to English-speaking countries), whose marriages are not recognised here, are likely to go elsewhere instead. Grieg argues that the long term impact on Australia's economy would be devastating, and even goes so far as to anticipate that among the growing chorus of voices worldwide calling for gay marriage 'it will be employers and big business that will become among the loudest’ (Grieg 2013). Just as Mayor Mandroux firmly coopted gay marriage as an instrument of reassertion of French Republican values, Grieg has clearly framed gay marriage as being first and foremost about the Big (or at least high-income professional) End of Town.

In a country that has since the beginning of the Howard years, and well into the Rudd then Gillard years, grappled with the incessant and growing demonisation of asylum seekers in particular and Muslims in general, or indeed anyone else who is other than white, professional and heterosexual (or modelled in that image), arguments such as Grieg's can appear at best clumsy and at worst, to be homonationalism (or homocapitalism) of the worst kind. This impression is only reinforced by consideration of the poverty statistics presented by ACOSS. It would seem that there are far more pressing issues of social and economic justice in Australia, including for our gay and lesbian populations, than gay marriage. Indeed, in a council community consultation forum in early May 2013, in my local Sydney area of Marrickville, a number of participants raised the problem of homelessness and poverty among many of Sydney's homosexuals, from young people having had to leave the family home to the elderly, unemployed and mentally ill. Concern was also raised, in what is ostensibly one of the most multicultural areas of the city, about the framing of all gays as white Anglo and all non-white-Anglo as somehow separate from the gay community, as almost by definition locked into traditions that cannot accommodate homosexuality. As Sandip Roy, who is of Indian origin, put it, many are consequently left 'unsure where [they] belong, suspended between [their] skin and [their] sexuality’ (Roy 2005).

Perhaps we are not as cosmopolitan as we think.

\section{Conclusion}

The campaigns for gay marriage, and the rhetoric with which governments — and their oppositions - embrace or refuse it, highlight the importance of marriageability for 
acceptance into the national community and for recognition as fully human. The nonmarriageable, according to Australian Marriage Equality, are considered 'second class citizens,' deprived of the 'protection by society and the state' that the United Nations advocates for formally recognised family units.

Gay marriage campaigns have thus been framed as in the interest of gay men and lesbians, in providing an 'in’ to this marital citizenship. Ultimately, however, marriage does not protect individuals or family members anywhere near as much as it protects the state. Marriage and family are regulators of social relations, creating structures in which it is in fact impossible for individuals to become the free and equal citizens that the lofty rhetoric of democracies tells us we should be. More importantly, marriage and the family are the primary vehicles of socioeconomic and cultural reproduction in the nation's image.

The least threatening thing to our heteropatriarchal white-Western capitalist states that gay rights activists can do, then, is to demand to marry and have families. As Shannon Gilreath has put it, if it values 'only that which is paradigmatically straight,' the gay movement will have ‘uncritically compromised its moral independence’ (Gilreath 2011: 229 and 232). As a result, we will all have become bound anew by the 'ties' of a heterosexist nation, and stigmatised anew if we seek to undo them.

\section{Reference List}

Ahmed, S. 2006, Queer Phenomenology: Orientations, Objects, Others. Duke University Press, Durham, NC.

Australian Council of Social Service 2012, 'Poverty in Australia,' ACOSS Paper 194, Sydney. Online, available: http://www.acoss.org.au/uploads/html/ACOSS_PovertyReport2012.html [Accessed 2 June 2013].

Australian Marriage Equality Website. Online, available: http://www.australianmarriageequality.com/wp/ [Accessed 2 June 2013].

Browne, K. 2011, “"By Partner We Mean ...”: Alternative Geographies of “Gay Marriage,”’ Sexualities, vol. 14, no. 1: 100-122.

Cameron, D. 2011, Keynote Speech, Conservative Party conference. Manchester, 5 October. Online, available: http://www.guardian.co.uk/politics/2011/oct/05/david-cameron-conservative-partyspeech [Accessed 1 June 2013].

Chasin, A. 2000, Selling Out: The Gay and Lesbian Movement Goes to Market. Palgrave, New York.

Commonwealth of Australia. 2011, Marriage Act 1961, as amended. Online, available: http://www.comlaw.gov.au/Details/C2011C00192 [Accessed 2 June 2013].

Chrisafis, A. 2013, 'France Celebrates First Gay Marriage amid Tight Security.' The Guardian, 29 May. Online, available: http://www.theguardian.com/world/2013/may/29/france-gay-rights [Accessed 14 October 2013].

Declaration of Montreal. 2006. Online, available: http://www.declarationofmontreal.org/declaration/DeclarationofMontreal.pdf [Accessed 1 June 2013]. 
Delphy, C. 2002, ‘A War for Afghan Women?,’ trans. B. Winter, in September 11, 2001: Feminist Perspectives, (eds) S. Hawthorne \& B. Winter. Spinifex, Melbourne: 302-315.

Dillon, M. 2011, 'Natalia Gaitán: crimen de odio,' Argentina Indymedia, 24 July. Online, available: http://argentina.indymedia.org/news/2011/07/787547.php [Accessed 2 June 2013].

Duggan, L. 2003, The Twilight of Equality: Neoliberalism, Cultural Politics, and the Attack on Democracy, Beacon, Boston.

2011, 'Beyond Marriage: Democracy, Equality, and Kinship for a New Century,' S\&F Online, vol. 10, no. 1-2. Online, available: http://sfonline.barnard.edu/a-new-queer-agenda/beyond-marriagedemocracy-equality-and-kinship-for-a-new-century/ [Accessed 31 May 2013].

Eisenstein, Z. 2007, Sexual Decoys: Gender, Race and War in Imperial Democracy. Zed Books, London and Spinifex Press, Melbourne.

'Folkwitness: Natalia Gaitán.’ 2011. Qualia Folk, 8 December. Online, available: http://www.qualiafolk.com/2011/12/08/folkwitness-natalia-gaitan/ [Accessed 2 June 2013].

Gilreath, S. 2011, The End of Straight Supremacy: Realizing Gay Liberation, Cambridge University Press, Cambridge.

Greenfield, N. 2011, 'LGBT Argentina Ready to Fight for Full Equality after Gay Marriage Made Legal,' The Huffington Post, 19 October. Online, available:

http://www.huffingtonpost.com/2011/10/18/argentina-gay-marriage_n_1018536.html [Accessed 2 June 2013].

Halberstam J. 2012, ‘Queers Create Betters Models of Success’ (Interview with Sinclair Sexsmith). Lambda Literary Review, 1 February 2012. Online, available: http://www.lambdaliterary.org/interviews/02/01/jack-halberstam-queers-create-better-models-ofsuccess/ [Accessed 14 October 2013].

Hopquin, B. \& Laurent. S. 2013, “"Manif pour tous”: après le succès, la réalité des chiffres,' Le Monde, 23 January. Online, available: http://www.lemonde.fr/societe/article/2013/01/23/manif-pour-tousapres-le-succes-la-realite-des-chiffres_1821120_3224.html [Accessed 2 June 2013].

Jansen, S. \& Spijkerboer, T. 2011, Fleeing Homophobia: Asylum Claims Related to Sexual Orientation and Gender Identity in Europe, COC \& Vrije Universiteit, Amsterdam. Online, available: http://www.rechten.vu.nl/nl/onderzoek/conferenties-en-projecten/conference-fleeing-homophobia/ [Accessed 15 October 2011].

Joseph, G. 2012, ‘Taking race seriously: Whiteness in Argentina’s National and Transnational Imaginary,' Identities: Global Studies in Culture and Power, vol. 7, no. 3: 333-371.

Kelly, A. 2010, 'Gay Weddings Boom under Argentina's New Liberal Laws,' The Observer, 26 December. Online, available: http://www.guardian.co.uk/world/2010/dec/26/argentina-buenosaires-gay-weddings [Accessed 1 June 2013].

Luibhéid, E. 2008, 'Queer Migration: An Unruly Body of Scholarship,' GLQ vol. 14, no. 2-3: 169-190.

Mamère, N. 2013, 'Dominique Venner, « martyr » d’un contre-mai 68,' Rue 89, 27 May. Online, available: http://blogs.rue89.com/chez-noel-mamere/2013/05/27/dominique-venner-martyr-duncontre-mai-68-230417 [Accessed 2 June 2013].

Manif pour tous, La. Website. Online, available: http://www.lamanifpourtous.fr [Accessed 2 June 2013].

Mercopress 2013, ““Official Poverty” in Argentina 2.5 Million People; Private Estimate: 11 Million.’ Mercopress, 25 April. Online, available: http://en.mercopress.com/2013/04/25/official-poverty-inargentina-2.5-million-people-private-estimate-11-million [Accessed 1 June 2013].

Millbank, J. 2009, 'From Discretion to Disbelief: Recent Trends in Refugee Determinations on the Basis of Sexual Orientation in Australia and the United Kingdom,' The International Journal of Human Rights, vol. 13, no. 2-3: 391-414.

Monde, Le, 2013, 'Le premier mariage homosexuel a été célébré en France.’ 29 May. Online, available: http://www.lemonde.fr/societe/article/2013/05/29/le-premier-mariage-homosexuel-a-eulieu_3420447_3224.html [Accessed 14 October, 2013].

Murphy, K. 2013, 'Tony Abbott Keeps Options Open on Same-Sex Marriage Conscience Vote.' The Guardian, 11 October. Online, available: http://www.theguardian.com/society/2013/oct/11/tonyabbott-keeps-options-open-on-same-sex-marriage-conscience-vote [Accessed 14 October 2013].

Nussbaum, M. C. 2000, Women and Human Development: The Capabilities Approach, Cambridge University Press, Cambridge.

Observatorio de la Deuda Social Argentina. 2013. 'Comunicado de prensa: estimaciones de tasas de indigencia y pobreza (2010-2012).’ Santa María de los Buenos Aires: Universidad Católica Argentina. Online, available: http://www.uca.edu.ar/uca/common/grupo68/files/INDIGENCIA_Y_POBREZA_20102012_INFORME_FINAL_04_2013.pdf [Accessed 31 May 2013]. 
Packham, B. 2013, ‘Julia Gillard Not Swayed by NZ Gay Marriage Vote,’ The Australian, 16 April. Online, available: http://www.theaustralian.com.au/national-affairs/julia-gillard-not-swayed-bynz-gay-marriage-vote/story-fn59niix-1226623243953 [Accessed 2 June, 2013].

Peatling, S. 2009, 'Same-Sex Couples Wary of Changes to Benefits,' The Sydney Morning Herald, 20 June. Online, available: http://www.smh.com.au/national/samesex-couples-wary-of-changes-tobenefits-20090619-cr84.html [Accessed 2 June 2013].

Pink News, 2010. 'Argentina Becomes first Country in Latin America to Legalise Gay Marriage.’ 15 July. Online, available: http://www.pinknews.co.uk/2010/07/15/argentina-becomes-first-country-inlatin-america-to-legalise-gay-marriage/ [Accessed 14 October 2013].

Polikoff, N. D. 1993, 'We Will Get What We Ask For: Why Legalizing Gay and Lesbian Marriage Will Not “Dismantle the Legal Structure of Gender in Every Marriage”,' Virginia Law Review, vol. 79: 1535-50.

Puar, J. K. 2006, Terrorist Assemblages: Homonationalism in Queer Times. Duke University Press, Durham.

Rawson, M.B. 2012, 'Ley de matrimonio igualitario y aborto en Argentina: notas sobre una revolución incompleta,' Estudios Feministas, vol. 20, no. 1: 173-188.

Roy, S. 2005, 'Can Gay Marriage Protect Europe From Subway Bombers?’ New America Media, 13 July. Online, available:

http://news.newamericamedia.org/news/view_article.html?article_id=a517da0536e361e88382124f 9dd53bb3 \{Accessed 2 June 2013].

Trouillard, S. 2013, 'France’s Marriage Equality Law is Less Equal for Some.’ France 24, 27 June. Online, available: http://www.france24.com/en/20130627-france-gay-marriage-law-same-sexequality-foreigners [Accessed 14 October, 2013].

United Nations General Assembly 2008, 'Statement on Human Rights, Sexual Orientation and Gender Identity,’ New York, 18 December. Online, available: http://www.refworld.org/docid/49997ae312.html [Accessed 1 June 2013].

Universal Islamic Declaration of Human Rights. 1981. Online, available: http://www.alhewar.com/ISLAMDECL.html [Accessed 2 June 2013].

Venner, D. 2013, 'La manif du 26 mai et Heidegger, Personal website, 21 May. Online, available: http://www.dominiquevenner.fr/2013/05/la-manif-du-26-mai-et-heidegger/ [Accessed 2 June 2013].

Vinter, H. 2010, 'Change Gonna Come: Gay Rights in Latin America.’ The Argentina Independent, 29 April. Online, available:

http://www.argentinaindependent.com/currentaffairs/newsfromlatinamerica/change-gonna-comegay-rights-in-latin-america/ [Accessed 2 June 2013].

Warner, Michael. 1999, 'Normal and Normaller: Beyond Gay Marriage.' GLQ Vol. 5 No. 2: 119-171.

Winter, B. 2002a, 'If Women Really Mattered...,' in September 11, 2001: Feminist Perspectives, (eds) S. Hawthorne and B. Winter. Spinifex, Melbourne: 450-80. 2002b, ‘The Politics of Assimilation: Are We Really “Family Too”?,' Word Is Out 5: 12-18. 2006, 'Religion, Culture and Women's Human Rights: Some General Political and Theoretical Considerations,' Women’s Studies International Forum vol. 29, no. 4: 381-93. 2009, 'Marianne Goes Multicultural: Ni putes ni soumises and the Republicanisation of Ethnic Minority Women in France.' French history and civilization: Papers from the George Rudé Seminar Vol. 2. Online, available: www.h-france.net/rude/rudeTOC2009.html [Accessed 3 October 2009].

2012, 'Sûr de rien: les demandeurs/euses d'asile homosexuels et lesbiennes face à l'idée des “pays sûrs”,' Australian Journal of French Studies vol. 49, no. 3: 280-294.

Yogyakarta Principles, The. 2006. Online, available: http://www.yogyakartaprinciples.org/principles_en.htm [Accessed 1 June 2013].

Yorukoglu, I. 2010, 'Marketing Diversity: Homonormativity and the Queer Turkish Organizations in Berlin,' in Islam and Homosexuality, vol. 2, (ed.) S. Habib, Praeger, Santa Barbara, CA.

Yue, A. 2008, 'Same-Sex Migration in Australia: From Interdependency to Intimacy,' GLQ, vol. 14, no. 2-3: 239-262. 